\title{
DEVELOPMENT OF AN AGILE ERP FRAMEWORK FOR IMPLEMENTATION: A SYSTEMATIC LITERATURE REVIEW
}

\author{
Santo Fernandi Wijaya ${ }^{1}$, Harjanto Prabowo ${ }^{2}$, Raymondus Raymond Kosala ${ }^{3}$ \\ and Meyliana ${ }^{4}$ \\ ${ }^{1}$ Computer Science Department, Doctor of Computer Science, \\ Bina Nusantara University, Jakarta, Indonesia \\ ${ }^{2}$ Information Systems Department, School of Information Systems, \\ Bina Nusantara University, Jakarta, Indonesia \\ ${ }^{3}$ Management Department, Binus Business School Undergraduate Program, \\ Bina Nusantara University, Jakarta, Indonesia \\ ${ }^{4}$ Computer Science Department, Faculty of Computing and Media, \\ Bina Nusantara University, Jakarta, Indonesia \\ ${ }^{1}$ santofw@binus.ac.id
}

\begin{abstract}
Organization has the innovate technology to compete in business. ERP system is one of technological innovations to help the managerial making decision making to improve the performance of companies. Thus, ERP is the important thing for organization's survival. Based on previous research that the organizations have complexity in ERP implementation. According to survey global study (2017) the most companies still use traditional methods to implement ERP, and they have ensured that agile methods are one solution and become the challenges in replacing traditional methods in stages. It considers that agile methods will improve efficiency, the speed of response, relatively achieve the simplicity in managing business processes. Therefore, it is better to understanding comprehensively about an implementation method in order to manage ERP implementation success. Thus, we intend to propose a method approaching the solution to improve the ERP implementation success. This paper, the authors are analyze using Systematic Literature Review to recognize the critical factors for development an agile ERP model that was selected 54 papers for further research. The research findings reveal for identifying the factors of the agile principles in order to improve the ERP implementation. The purpose of this paper is to mapping the critical factors for practices to development of the agile ERP model.
\end{abstract}

Keywords - Development, Agile ERP framework, ERP implementation

\section{INTRODUCTION}

In the technology transformation, so the ERP value is the important strategy of organization to ensure that it is possible to provide the best solutions in order to enhance the organization performance. ERP systems can give the solution to contribute to making decision. But in the fact, the organizations still have the complexity in ERP implementation. The Critical Failure Factors (CFFs) of ERP implementation as follows: excessive customization (27\%); internal integration dilemma (18\%); change management $(16 \%)$; data quality (16\%) [6]. these factors are the challenges for organization to enhance 
the quality of ERP implementation. Based on previous research which the critical factors of ERP failure is the implementation method. Therefore, it is better to understand how to develop a new method for manage ERP implementation. Most organizations still use traditional methods of implementing ERP. For this reason, it is necessary to consider using other methods to implement ERP. The agile method is one of the method that should be considered in ERP implementation. Thus, the agile method can give the solution about the inability with the business process reengineering to follow business process of the ERP system available. The goal of this study is for developing an agile ERP model that contribute to enhance the quality of ERP implementation with the answer of the research question (RQ) as follows:

RQ1 How to explain an agile model is used for ERP system?

RQ2 What framework is needed to accomplish the ERP system?

RQ3 What is the Critical Success Factors (CSFs) of an agile framework for ERP system?

\section{THEORETICAL BACKGROUND}

\subsection{AGILE METHOD}

The agile model can verify for managing the project system to provide the contribution for support environment change [45]. The agile model is more flexible to treatment change of requirement and increasing productivity [20]. The agile model is effective in some tricky software development to effective business process [36]. The agile model has developed a decision of agile method to more adaptive in process [17]. And methods have gotten a good reputation for managing projects management. Because the agile model has benefit such as Focusing on business needs, on time, collaborating, product quality, developing gradually from a strong foundation, developing iteratively, communicating continuously, and exercising control. So, the agile model can be developed to improve the quality of ERP implementation

\subsection{AGILE METHOD PRINCIPLE}

The principle of the agile method is to satisfy customers and make changes to business processes that aim to provide the role of the application to work optimally. The principle of the agile method also consists of process, people, product, and practice factors, which focus on meeting business needs, sending in a timely manner, collaborating information, communicating and interacting intensively and clearly, as well as carrying out a strict supervision process in an effort to improve organizational performance [56 and 57]. The principle of the agile method can be shown in the following table: 
Table I. The Principles of the Agile Approach

\begin{tabular}{|c|c|}
\hline COMPONENTS & FACTORS \\
\hline \multirow{4}{*}{$\begin{array}{l}\text { Focus on the business } \\
\text { need }\end{array}$} & Understand \& respect true business priorities \\
\hline & Establish valid business case \\
\hline & Ensure contintuous business sponsorship \& commitment \\
\hline & Guarantee delivery of minimum usable subset \\
\hline \multirow{4}{*}{ Deliver on time } & Timebos the work \\
\hline & Focus on business priorities \\
\hline & Always hit deadlines \\
\hline & Build confidence throuph predictable delivery \\
\hline \multirow{3}{*}{ Collaborate } & Involve the right stakeholders at the right time throughout the project \\
\hline & $\begin{array}{l}\text { Ensure team menbers are empowered to take decisions on behalf of } \\
\text { they represent }\end{array}$ \\
\hline & Build a one team culture \\
\hline \multirow{4}{*}{$\begin{array}{l}\text { Never compromise } \\
\text { quality }\end{array}$} & Agree the level of quality from outset before development starts \\
\hline & Ensure quality doesnot become a variable \\
\hline & Test early, test continuously \& test to appropriate level \\
\hline & Desing \& document appropriately \\
\hline \multirow{2}{*}{$\begin{array}{l}\text { Build incrementally } \\
\text { from firm fonandations }\end{array}$} & $\begin{array}{l}\text { Do appropriate analysis \& enough design op front to create } \\
\text { foundations for subsequent work }\end{array}$ \\
\hline & With each delivered increment \\
\hline \multirow{3}{*}{ Develop iteratively } & Build business feedback into each iteration \\
\hline & Recognise that most detail should emerge later, rafther than sooner \\
\hline & Embrace change \\
\hline \multirow{5}{*}{$\begin{array}{l}\text { Communicate } \\
\text { continuously and clearly }\end{array}$} & Make full and proper use of apile practices \\
\hline & $\begin{array}{l}\text { Provide opportunites for those interested to keep themselves } \\
\text { informed project through visible activity and outputs }\end{array}$ \\
\hline & Keep documentation leas and timely \\
\hline & Manage stakeholder expectations at all levels \\
\hline & Always aim for honevty $\&$ trausparency \\
\hline \multirow{3}{*}{ Demonstrate coutrol } & Malce plans \& progress visible to all \\
\hline & Measture propress throult focus on delivery of products \\
\hline & Use appropriate level of formality for tracking \& reporting \\
\hline
\end{tabular}

The principle of the agile method will build from an iteration to iteration and new features that can be added to the next iteration. It aims to harmonize changes in business processes and increase and add value to a system development project. The principle of the agile method will make a process of change in the development of information systems. The agile principle is used as an approach to developing a responsive and dynamic system of change so that it is possible to work proactively to manage changes in business processes and work more intelligently in order to improve the effectiveness and productivity. The agile methods issues are responsive for achieving information system project success, with focus the factors such as strategies, agile project management, systems, process, management, methodology, technologies, people and organization [58].

\subsection{FRAMEWORK MODEL}

The benefit of ERP system requires an understanding of IT-enabled organizational by developing the emergent business process [23]. The development of agile framework is an example for achieving simplicity of the business process. 
Table II. Framework for ERP Implementation - Adopted from [37]

\begin{tabular}{|c|c|c|}
\hline Pre-Implementation (setting up) & Implementation & Post-Implementation (evaluation) \\
\hline $\begin{array}{l}\text { - Clear understanding of strategic goals } \\
\text { for ERP } \\
\text { - Commitment by top management } \\
\text { - Cultural \& structural changes } \\
\text { readiness }\end{array}$ & $\begin{array}{l}\text { - Excelent project management } \\
\text { - ERP package selection } \\
\text { - Open information \& communica- } \\
\text { tion policy } \\
\text { - Exhaustive analysis of current } \\
\text { business processes } \\
\text { - Importance of data accuracy } \\
\text { - IT leveragability \& knowledge } \\
\text { capability } \\
\text { - Great implementation team } \\
\text { - Focuses performance measures } \\
\text { - Appropriate celebration when } \\
\text { project completed }\end{array}$ & $\begin{array}{l}\text { - Post implementation audit } \\
\text { - Documentation \& advertising ERP } \\
\text { success } \\
\text { - Correspondence success } \\
\text { - Process success } \\
\text { - Interaction success } \\
\text { - Expectation success } \\
\text { - Benchmarking }\end{array}$ \\
\hline
\end{tabular}

\subsection{OVERVIEW OF ERP IMPLEMENTATION}

ERP implementation has the significant affect in order to improve the organization performance to process change [22]. The other case, the challenge of ERP implementation can provide the competitive advantage of organizations to increase operational to be more effective [2]. The key success factors of ERP system as follows [25]:
a. Identifying change of system configuration changes to confirm business conditions;
b. Recruiting human resource as requirement skilled personnel within the conducting training programs;
c. Developing project plan to change management;
d. Decides with the consultant to determine of software and hardware components;
e. Go-live for timely ERP systems.

\subsection{AGILE METHOD FOR ERP IMPLEMENTATION}

An agile method for ERP implementation has been devised for combining agile of ERP systems, as follows: [35]

a. Envision - To construct an understanding concept of the purpose of using the system.

b. Iterate - To recognize the ERP solution for requirements of the user satisfy.

c. Decide - To determine of the ERP selected

The framework to evaluate post-implementation process to prove the trial system, checking reliability, data integrity, system utilization, and examine the benefits of ERP implementation [43]. 


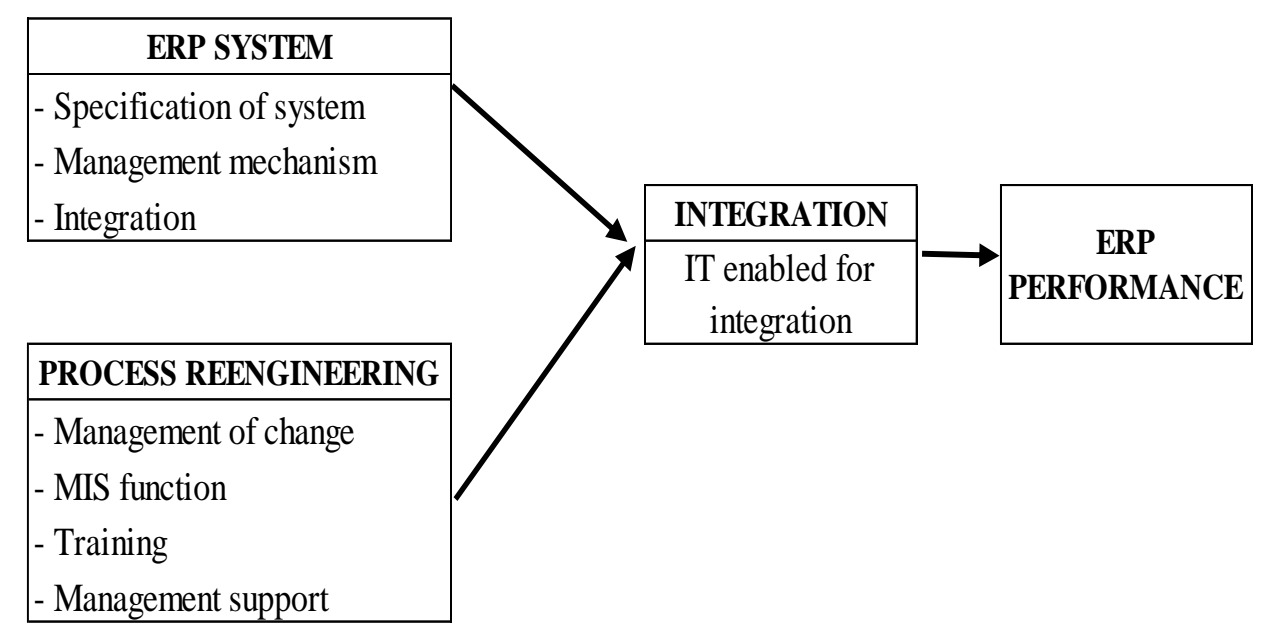

Fig. 1 An agile framework of ERP implementation

\section{RESEARCH METHOD}

This paper uses a literature review that is adjusted to the provisions by [55].

\subsection{DATA SOURCE}

The search method conducted by researchers in this research is to use keywords by determining the search string as follows:

a. ("agile") AND ("methods")

b. ("new") AND ("framework" OR "agile" AND "framework")

c. ("erp") AND ("implementation" OR "agile" AND "framework")

Search terms assigned according to "agile framework ERP implementation" for searching the papers.

\subsection{DESCRIPTION FOR INCLUSION CRITERIA AND EXCLUSION CRITERIA}

In this study, the authors used a series of selection inclusion criteria and exclusion criteria to select appropriate papers to answer research questions. 
Table III. Inclusion and Exclusion of Papers Selected

Inclusion criteria

- The criteria of studies are the describe agile method and ERP implementation approaches

- The papers published between 2005 and 2017.

- The conference or journal with computer science or information system.

- Studies included articles where the review of literature was the key article.

- The papers that according to quantitative research or qualitative research or a mix both.

Exclusion criteria

- The studies are not related to the topic of this study.

- The papers were the published before of the year 2005.

- The studies with non-academic databases.

- Duplicate articles found on the digital libraries

- The study is not written in English.

- The studies are not covering agile framework ERP implementation.

- The papers have a weak analysis, such as unpublished paper, opinion and poster session.

\subsection{DATA COLLECTION}

The authors manage and collect data by searching for titles, keywords, abstracts, and conducting a full-text analysis to determine and find information that matches the selected paper. Based on the results of data processing, the researcher will process by grouping into the following:

a. Studies found: It was a paper found in accordance with the keywords that matched the topic of this research.

b. Candidate selection: It is a paper by reviewing the title, keywords, and abstracts that are in accordance with the topic of the research.

c. Selected: An optional paper for conducting an overall review, as material for mapping and further analysis.

Table IV. Source of Studies

\begin{tabular}{|c|c|c|c|}
\hline Source & $\begin{array}{l}\text { Studies } \\
\text { Found }\end{array}$ & $\begin{array}{c}\text { Candidated } \\
\text { Studies }\end{array}$ & $\begin{array}{l}\text { Selected } \\
\text { Studies }\end{array}$ \\
\hline$\overline{\mathrm{ACM}}$ & 154 & 10 & 5 \\
\hline Elsevier & 836 & 56 & 8 \\
\hline Emerald & 753 & 35 & 13 \\
\hline IEEE & 955 & 31 & 7 \\
\hline Inderscience & 567 & 7 & 1 \\
\hline Other & 81 & 67 & 10 \\
\hline Springer & 1090 & 29 & 3 \\
\hline Taylor \& Francis & 412 & 39 & 5 \\
\hline \multirow[t]{2}{*}{ Wiley Online } & 190 & 9 & 2 \\
\hline & 5038 & 283 & 54 \\
\hline
\end{tabular}

The following are the steps carried out by authors in processing data based on 54 papers selected to carry out further analysis in finding answers from research questions 


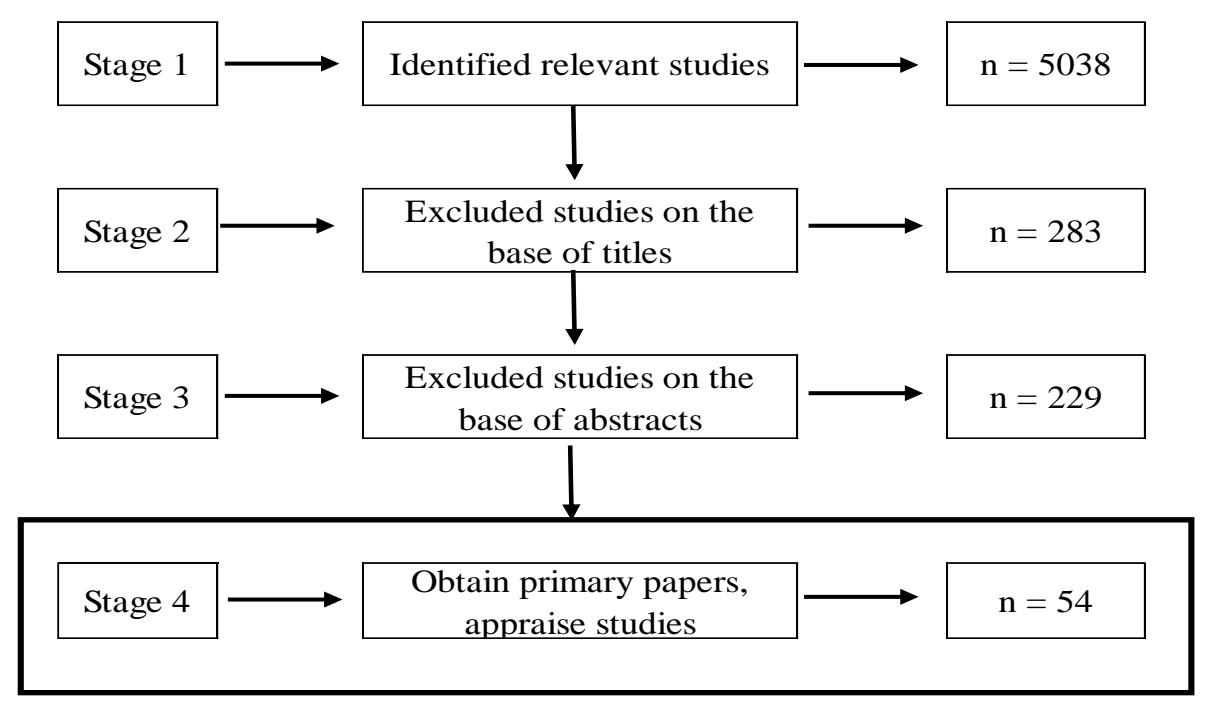

Fig. 2 Stage of Studies Selection Process

Figure 2, the authors have reviewed all papers based on keywords, titles, and abstracts which are mapping to match the inclusion criteria. Stage1, Based on 5038 papers selected that acknowledge relevantly are selected papers for detailed reviews. Stage2, Based on 283 papers as candidate selection. Stage3, based on 229 papers for detailed reviews. Stage 4, Based on 54 papers as the main papers for processing data to answer the research questions.

\subsection{DATA ANALYSIS}

The analysis of data categories utilized in this study was:

a. The number of article type published based on the data source.

b. Research type that supported an agile method, framework model, and ERP implementation approach.

c. The number of study relevant with this research.

d. The quality score for each article type.

\section{RESULT}

The authors have examined for the mapping activity for the answer to research questions.

\subsection{SEARCH RESULTS}

The authors processed 54 papers as the main paper. The results of data processing is shown in Table V. The mapping CSFs of component according to literature shows that It indicates the component factors consist of organizational, process, people, systems, technology. 
Table V. Mapping CSFs components using the literature

\begin{tabular}{|c|c|c|c|c|c|c|}
\hline \multirow{2}{*}{ 菅 } & \multirow{2}{*}{ COMPONENT } & \multicolumn{4}{|c|}{ Research focus } & \multirow{2}{*}{ REFERENCES } \\
\hline & & Agile & Framework & ERP & Freq & \\
\hline \multirow{23}{*}{ 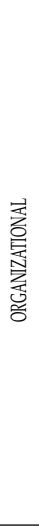 } & $\begin{array}{l}\text { Baseline and Sprint realization } \\
\text { External pressures }\end{array}$ & & & $v_{v}^{v}$ & ${ }_{1}^{1}$ & {$[28]$} \\
\hline & $\begin{array}{l}\text { External pressures } \\
\text { Trust }\end{array}$ & & & $v$ & 1 & [51] \\
\hline & Benchmarking & & $v$ & & 1 & [5] \\
\hline & $\begin{array}{l}\text { Change management plan } \\
\text { Clear goals \& objective }\end{array}$ & $\checkmark$ & * & $v$ & 8 & {$[30] ;[31] ;[32] ;[38] ;[47] ;[51] ;[52] ;[18]$} \\
\hline & Common knowledge & $v$ & r & & 1 & [21] \\
\hline & Completeness: sustained, maintained & & $v$ & & 1 & \\
\hline & & $\mathrm{v}$ & & & 3 & {$[18] ;[20] ;[21]$} \\
\hline & $\begin{array}{l}\text { Customer collaboration } \\
\text { Customer involvement }\end{array}$ & $\begin{array}{l}v \\
v\end{array}$ & & & $\frac{2}{2}$ & $\begin{array}{l}{[20] ;[45]} \\
{[21] ;[45]}\end{array}$ \\
\hline & Daily discussion & & & & 1 & {$[21]$} \\
\hline & $\begin{array}{l}\text { Effective \& timely communications } \\
\text { Effective method }\end{array}$ & $v$ & $v$ & $\mathrm{v}$ & 9 & {$[26] ;[30] ;[31] ;[33] ;[38] ;[47] ;[5] ;[48] ;[20]$} \\
\hline & $\begin{array}{l}\text { Evaluation of Management } \\
\text { Evaluat }\end{array}$ & & & $v$ & 1 & 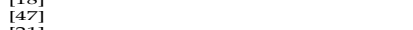 \\
\hline & Evolving and hierarchical specification & $v$ & & $\gamma$ & 1 & [21] \\
\hline & $\begin{array}{l}\text { Funds } \\
\text { Individual and interactions }\end{array}$ & $v$ & & & 1 & {$[28]$} \\
\hline & 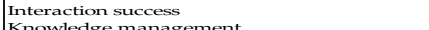 & & $v$ & $v$ & $\frac{1}{2}$ & \\
\hline & $\mid \begin{array}{l}\text { Knowledge management } \\
\text { Lean, flexibility \& iterative }\end{array}$ & $v$ & & $v$ & ${ }_{1}^{2}$ & [12]; [47] \\
\hline & Learning loop & $v$ & & & & [21] \\
\hline & $\begin{array}{l}\text { Management support \& commitment } \\
\text { Commitments \& emotional involvement }\end{array}$ & & $\stackrel{v}{v}$ & $\mathrm{v}$ & ${ }_{1}^{11}$ & {$[26] ;[28] ;[30] ;[31] ;[32] ;[38] ;[47] ;[51] ;$} \\
\hline & Organization readness \& transparancy & & & $v$ & 4 & [26]; [30]; [38]; [52] \\
\hline & Organizational change, structural \& cultural & $v$ & $v$ & $v$ & 14 & $\begin{array}{l}\text { [187; [112]; [30]; [53]; [5]; [24]; [25]; [12]; [30]; } \\
\text { [477; [51]; [5]; [24]; } 25]\end{array}$ \\
\hline & Project Management & & $v$ & $v$ & 8 & [12]; [26]; [31]; [38]; [51];[52]; [5]; [48] \\
\hline & $\begin{array}{l}\text { Responding to change } \\
\text { Size of organization }\end{array}$ & $v$ & v & & $\frac{1}{2}$ & $[20] ; ; 25]$ \\
\hline & Small cross-functional teams & $v$ & & & 1 & [21] \\
\hline & Transformation leadership & & & $\mathrm{v}$ & 1 & [12] \\
\hline \multirow{10}{*}{$\begin{array}{l}\text { 岛 } \\
\text { O }\end{array}$} & $\begin{array}{l}\text { Agile implementation } \\
\text { Business implication and requirements }\end{array}$ & $\mathrm{v}$ & & $v$ & $\frac{1}{2}$ & [30]; [32] \\
\hline & $\begin{array}{l}\text { Business process alignment } \\
\text { Busines process behaviors, dependencies }\end{array}$ & & $\underset{v}{v}$ & & 1 & {$[8]$} \\
\hline & Business Process Reengineering & $\checkmark$ & $\mathrm{v}$ & $v$ & 9 & {$[26] ;[28] ;[30] ;[38] ;[47] ;[51] ;[53] ;[18] ;[5]$} \\
\hline & $\begin{array}{l}\text { Code review } \\
\text { Improve the quality of ERP system }\end{array}$ & $\stackrel{v}{v}$ & & & & {$[45]$} \\
\hline & $\begin{array}{l}\text { Improve the quality of ERP system } \\
\text { Implementation time }\end{array}$ & $v$ & & $v$ & 1 & {$[16]$} \\
\hline & $\begin{array}{l}\text { Process champion success } \\
\text { Product vision }\end{array}$ & $v$ & $v$ & $v$ & 4 & [31]; [47]; [5]; [48] \\
\hline & Simplicity & $v$ & & & 2 & {$[21]:[45]$} \\
\hline & Availability of usage frameworks & & $v$ & & & {$[5] ;[45]$} \\
\hline & Value objects, activities, goals, dependencies & & $\mathrm{v}$ & & 1 & [8] \\
\hline & Working software & 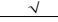 & $\mathrm{v}$ & & 4 & {$[20] ;[18] ;[24] ;[25]$} \\
\hline \multirow{6}{*}{ 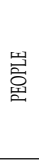 } & $\begin{array}{l}\text { External consultant support } \\
\text { Lack of human \& financial resources }\end{array}$ & & & $v$ & ${ }_{1}^{4}$ & {$\left[\begin{array}{l}{[26] ;[31] ;[48] ;[24]} \\
{[33]}\end{array}\right.$} \\
\hline & Motivated people & $v$ & & & 1 & [20] \\
\hline & $\begin{array}{l}\text { Outcome review } \\
\text { People interaction }\end{array}$ & $v$ & & & $\begin{array}{l}1 \\
1\end{array}$ & {$\left[\begin{array}{lll}211 \\
{[20]}\end{array}\right]$} \\
\hline & Skill manpower & & & $v$ & 1 & [28] \\
\hline & $\begin{array}{l}\text { Time allocation } \\
\text { Unattached communicative team }\end{array}$ & $v$ & & & $\begin{array}{l}1 \\
1\end{array}$ & {$\left[\begin{array}{l}{[45]} \\
{[211}\end{array}\right.$} \\
\hline & User training and education & $\checkmark$ & $v$ & $v$ & 11 & 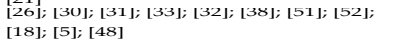 \\
\hline \multirow{11}{*}{ 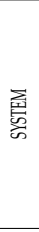 } & Delivering frequent releases & v & & & 2 & {$[21] ;[18]$} \\
\hline & Minimum change requirement & $\mathrm{v}$ & & & 1 & [45] \\
\hline & Progress monitoring & $v$ & & & 1 & [21] \\
\hline & $\begin{array}{l}\text { Regular intervals } \\
\text { Tailoring }\end{array}$ & $\begin{array}{l}v \\
v \\
v\end{array}$ & & $v$ & $\begin{array}{l}1 \\
3\end{array}$ & [18] $[12] \cdot[30]$ \\
\hline & Technical excellence \& good design & $v$ & & & 1 & $[20],[12] ; 00]$ \\
\hline & $\begin{array}{l}\text { Validation practice } \\
\text { Cost schedule planned functionality }\end{array}$ & $v$ & & & 1 & {$[21]$} \\
\hline & $\begin{array}{l}\text { Cost, schedule, planned functionality } \\
\text { Excessive customization }\end{array}$ & & & $\begin{array}{c}v \\
v\end{array}$ & ${ }_{1}^{2}$ & [32]; [51] \\
\hline & $\begin{array}{l}\text { Information quality } \\
\text { Inton }\end{array}$ & & $v$ & & 2 & [25]; [8] \\
\hline & Post implementation audit & & $\mathrm{v}$ & & 3 & {$[5] ;[24] ;[25]$} \\
\hline & Sistems quality & & & & 2 & [24]; [25] \\
\hline & $\begin{array}{l}\text { Soltware development } \\
\text { System integrating }\end{array}$ & & & $v$ & 2 & {$\left[\begin{array}{l}{[12][30]} \\
{[32][52]}\end{array}\right.$} \\
\hline \multirow{4}{*}{$\begin{array}{l}\text { ह0 } \\
\text { 总 } \\
\text { 总 } \\
\text { E }\end{array}$} & Alignment IT with business & & & $v$ & 1 & [32] \\
\hline & Data fill in & & & $v$ & 1 & [28] \\
\hline & IT legacy systems management & 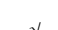 & $v$ & & 3 & [5]; [24]; \\
\hline & & $\checkmark$ & & & & \\
\hline
\end{tabular}

\subsection{QUALITY FACTORS}

The authors evaluated the related factors of quality scores for published date articles. The results of data processing is shown in Table VI.

Table VI. Quality Scores of Studies (by publication date)

\begin{tabular}{|c|c|c|c|c|c|c|c|c|c|c|c|}
\hline Year & $\begin{array}{l}\text { Mean } \\
\text { quality } \\
\text { score }\end{array}$ & $\begin{array}{c}\text { Number } \\
\text { of } \\
\text { studies }\end{array}$ & $\sum_{i}$ & 离 & 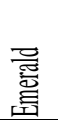 & 罳 & $\begin{array}{l}\text { 总 } \\
\text { 密 } \\
\text { 总 }\end{array}$ & $\frac{\bar{\Xi}}{\delta}$ & 颜 & 离 & $\begin{array}{l}\text { 兰 } \\
\text { 离 }\end{array}$ \\
\hline 2017 & 3.00 & 4 & O & 0 & 3 & 0 & 0 & $\mathrm{O}$ & O & 1 & $O$ \\
\hline 2016 & 2.50 & 9 & 1 & 2 & 1 & 2 & O & 2 & O & 1 & O \\
\hline 2015 & 2.56 & 9 & O & 2 & 1 & O & O & 4 & 1 & O & 1 \\
\hline 2014 & 2.56 & 9 & 1 & O & 2 & 3 & 1 & 2 & O & O & O \\
\hline 2013 & 2.75 & 2 & 1 & O & O & O & O & O & O & 1 & O \\
\hline 2012 & 2.63 & 4 & 1 & O & 2 & O & O & 1 & O & O & O \\
\hline 2011 & 2.50 & 3 & O & O & $\mathbf{O}$ & O & O & 1 & 1 & O & 1 \\
\hline 2010 & 2.75 & 2 & O & O & 2 & O & O & O & O & O & O \\
\hline 2009 & 2.50 & 2 & O & O & 1 & O & O & O & 1 & O & O \\
\hline 2008 & 2.50 & 3 & O & 1 & O & 1 & O & O & O & 1 & O \\
\hline 2007 & 2.50 & 1 & O & O & O & O & O & O & O & 1 & O \\
\hline 2006 & - & O & O & O & O & O & O & O & O & O & O \\
\hline \multirow[t]{2}{*}{2005} & 2.33 & 6 & 1 & 3 & 1 & 1 & O & O & O & O & O \\
\hline & 2.39 & 54 & 5 & 8 & 13 & 7 & $\mathbf{1}$ & 10 & 3 & 5 & 2 \\
\hline
\end{tabular}

Table VI shows that the number of papers published shows a relatively stable trend with an average scored 2.39 . 


\section{DISCUSSION}

In this section, the authors have shown the result of mapping to answer the research questions.

\subsection{HOW TO EXPLAIN AN AGILE FRAMEWORK IS USED FOR ERP SYSTEM?}

The purpose of this research question is to show the method aspects used in an agile framework for ERP implementation research. The empirical research that it is an increasing trend.

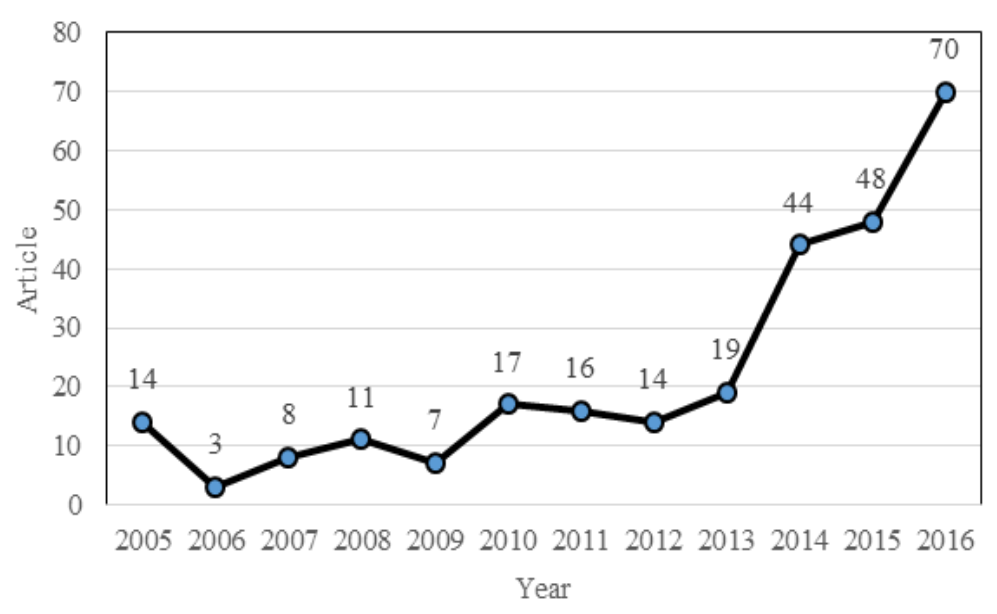

Fig. 3 The number of studies on agile framework ERP implementation

Figure 3 shows that the papers published an upward trend in trends. So, the agile framework for ERP implementation studies has the opportunity for further research.

\subsection{WHAT FRAMEWORK IS NEEDED TO ACCOMPLISH THE ERP SYSTEM?}

The purpose of this research question is to demonstrate the methodological aspects ued in the framework model for ERP implementation research.

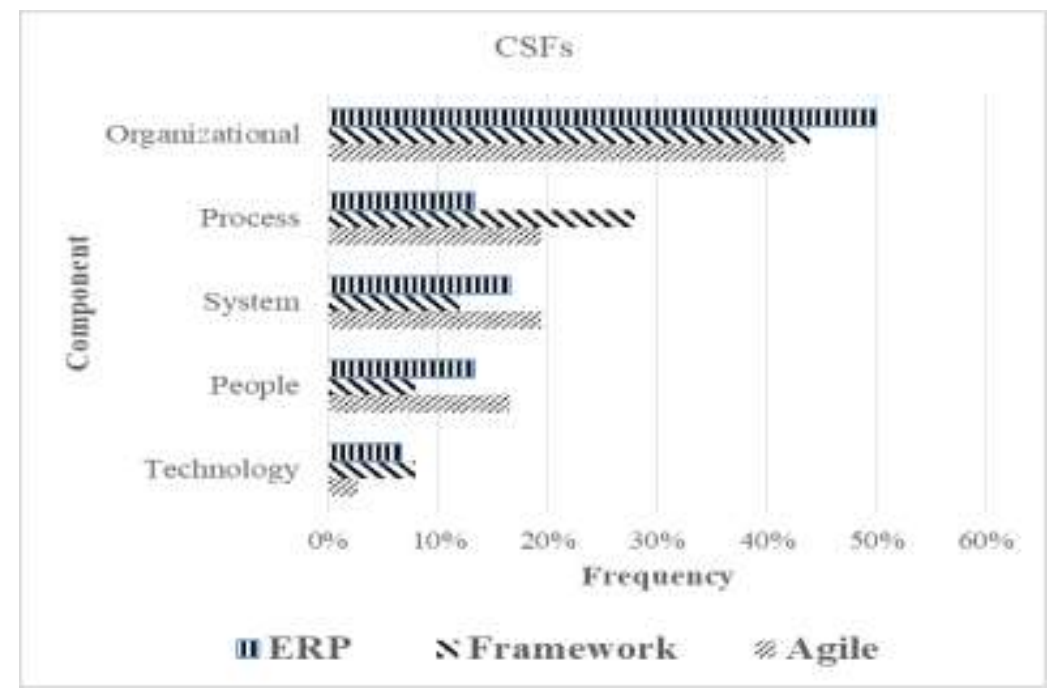

Fig. 4 Summary CSFs Component 
Figure 4 show that the Critical Success Factors issue of framework model for ERP implementation have influence in organizational $(50 \%) ; \operatorname{process}(13 \%) ; \operatorname{system}(17 \%)$; people(12\%); technology(7\%). The result of this analysis that the most important of framework model is organizational. So, the organizations readiness have decided to make the organizational change in determine ERP implementation.

\subsection{WHAT IS CRITICAL SUCCESS FACTORS (CSFS) OF AN AGILE FRAMEWORK FOR ERP SYSTEM?}

The purpose of this research question is to show the method aspects used in agile framework for ERP implementation research. Figure 4 indicates that the CSFs issue of framework model for ERP implementation have influence in organizational(44\%); process $(28 \%)$; system(12\%); people( $8 \%)$; technology $(8 \%)$. Figure 4 indicates that the CSFs issue of agile method for ERP implementation have influence in organizational(42\%); process (19\%); system(19\%); people(17\%); technology(3\%). So, the summary based on Figure 4, the CSF issue of an agile framework is organizational. The organizational have the important strategy for identifying an agile framework effectively to support ERP implementation.

\subsection{LIMITATION AND FUTURE RESEARCH}

This study only analyzes paper based on the SLR approach to recognize the agile model for ERP systems, And also the authors just make analyze for general organizations with the limitations on industry samples. Therefore, the author has accepted that this study has limitations and needs to be improved in future research by proving that agile frameworks are suitable and focus on case studies from various industries as objects with to develop for model agile ERP for enhance the quality of ERP implementation.

\section{CONCLUSION}

This research has the contribute to identifying the critical factors of an agile ERP model research using SLR methodology and having the significant impact for identifying the critical factors for implementation of ERP. Thus, the agile ERP model can be considered to enhance the quality ERP implementation. The critical factors of model agile ERP are organizational, process, system, process and technology. These factors have significant functions and have important contribution values in supporting quality improvement in ERP implementation. Beside that, agile ERP model has benefit such as focusing on business needs, on time, collaborating, product quality, developing gradually from a strong foundation, developing iteratively, communicating continuously, and exercising control. For this reason, the build of agile ERP model can be considered as the best solution to achieve implementing ERP success for the organizations.

\section{REFERENCES}

[1] Chand D, Hachey G, Hunton J, Owhoso V, \& Vasudevan S., "A balanced scorecard based framework for assessing the strategic impacts of ERP systems", Computers in industry, 56(6), (2005), pp. 558-572.

[2] Panayiotou NA, Gayialis SP, Evangelopoulos NP and Katimertzoglou PK, "A business process modeling-enabled requirements engineering framework for ERP implementation", Business Process Management Journal, 21(3), (2015), pp. 628-664.

[3] Ulziit B, Warraich ZA, Gencel C, \& Petersen K., "A conceptual framework of challenges and solutions for managing global software maintenance", Journal of Software: Evolution and Process, 27(10), (2015), pp. 763.

[4] Cao L, Mohan, Xu, \& Ramesh, "A framework for adapting agile development methodologies", European Journal of Information Systems, 18(4), (2009), pp. 332-343.

[5] Gupta R \& Naqvi SK, "A framework for applying critical success factors to ERP implementation projects", International Journal of Business Information Systems, 17(4), (2014), pp. 469-490. 
[6] Momoh A, "A framework for complexity cost modelling of ERP implementation", Dspace.lib.cranfield.ac.uk. (2015).

[7] Sagheer M, Zafar T, \& Sirshar M, "A Framework for Software Quality Assurance Using Agile Methodology", International Journal of Scientific and Technology Research, 4(02), (2015), pp. 44-50.

[8] Solaimani S \& Bouwman H, "A framework for the alignment of business model and business processes: A generic model for trans-sector innovation", Business Process Management Journal, 18(4), (2012), pp. 655-679.

[9] Najmi M, Rigas J, \& Fan IS, “A framework to review performance measurement systems", Business Process Management Journal, 11(2), (2005), pp. 109-122.

[10] Vilpola IH, "A method for improving ERP implementation success by the principles and process of user-centred design", Enterprise Information System, (2008), pp. 47-76.

[11] Jamshidi A, Rahimi SA, Bartolome AR, \& Ait-kadi D, "A new framework for risk assessment in ERP maintenance", In Reliability and Maintainability Symposium (RAMS), Annual, IEEE, (2014), pp. 1-6.

[12] Grabski SV, Leech SA \& Schmidt PJ, "A review of ERP research: A future agenda for accounting information systems", Journal of information systems, 25(1), (2011), pp. 37-78.

[13] Badr NM, Elabd E, \& Abdelkader HM, "A Semantic Based Framework for Facilitating Integration in ERP Systems", In Proceedings of the 10th International Conference on Informatics and Systems, ACM, (2016), pp. 35-42.

[14] McAvoy J, Sammon D \& Owens I, "A simple tool to assist in agile methodology adoption decisions", Journal of Decision Systems.16(4), (2007), pp. 451-468.

[15] Wu LC, Ong CS, \& Hsu YW, “Active ERP implementation management: A Real Options perspective”, Journal of Systems and Software, 81(6), (2008), pp. 1039-1050.

[16] Jovicic B, Devedzic V, Djuric D, \& Sendelj R, "Agile ERP systems development: a technical perspective", In Proceedings of the 5th India Software Engineering Conference, ACM, (2012), pp. 7174.

[17] Tripp JF and Armstrong DJ, "Agile Methodologies: Organizational Adoption Motives, Tailoring, and Performance", (2016), pp. 1-10.

[18] Wachnik B, "Agile Methodology as a tool for reducing information asymmetry in the implementation of it projects completed on the basis of the outsourcing strategy", Information Systems in Management, 5, (2016).

[19] Fox D, Sillito J, \& Maurer F, "Agile methods and user-centered design: How these two methodologies are being successfully integrated in industry", In Agile, Conference, IEEE, (2008), pp. 63-72.

[20] Campanelli AS \& Parreiras FS, "Agile methods tailoring-A systematic literature review", Journal of Systems and Software, (2015), pp. 110.

[21] Diebold P \& Dahlem M, “Agile practices in practice: a mapping study", In Proceedings of the 18th International Conference on Evaluation and Assessment in Software Engineering, ACM, (2014), pp. 30.

[22] Zouaghi I \& Laghouag A, "Aligning key success factors to ERP implementation strategy: learning from a case study", International Journal of Business Information Systems, 22(1), (2016), pp. 100-115.

[23] Staehr L, Shanks G, \& Seddon PB, "An explanatory framework for achieving business benefits from ERP systems", Journal of the Association for Information Systems, 13(6), (2012), pp. 424.

[24] Zare A \& Ravasan AZ, "An extended framework for ERP post-implementation success assessment", Information Resources Management Journal (IRMJ), 27(4), (2014), pp. 45-65.

[25] Kalinga Jagoda \& Premaratne Samaranayake, "An Integrated Framework for ERP System Implementation", International Journal of Accounting \& Information Management, vol. 25, (2017).

[26] Tarhini A, Ammar H, \& Tarhini T, "Analysis of the critical success factors for enterprise resource planning implementation from stakeholders' perspective: A systematic review", International Business Research, 8(4), (2015), pp. 25.

[27] Fetouh AA, el Abbassy A, \& Moawad R, "Applying Agile Approach in ERP Implementation", IJCSNS, 11(8), (2011), pp. 173.

[28] Tareq Q, “Avoiding the Most Common ERP Challenges with Agile Method”, (2016).

[29] Wong WP, "Business-process management: a proposed framework for future research", Total Quality Management \& Business Excellence, 24(5-6), (2013), pp. 719-732.

[30] Nandi ML, Nandi ML, Kumar A., "Centralization and the success of ERP implementation", Journal of Enterprise Information, 29(5), (2016), pp. 728-750.

[31] Dikert K, Paasivaara M, \& Lassenius C., "Challenges and success factors for large-scale agile transformations: A systematic literature review", 119, (2016), pp. 87-108.

[32] Momoh A, Roy R, \& Shehab E., "Challenges in enterprise resource planning implementation: state-ofthe-art", Business Process Management, (2010), pp. 537-565.

[33] Zamre N \& Ismail S., "Challenges in Managing the ERP Implementation: Case Study on User Requirement Stage", In Proceedings of IC-ITS International Conference on Information Technology \& Society, (2015), pp. 395-405.

[34] Nerur S, Mahapatra R, Mangalaraj G., "Challenges of migrating to agile methodologies", Communications of the ACM, 48(5), (2005), pp. 72-78.

[35] Nagpal S, Khatri S K, \& Kumar A., "Comparative study of ERP implementation strategies", In Systems, Applications and Technology Conference (LISAT), IEEE Long Island, (2015), pp. 1-9. 
[36] Mishra D \& Mishra A., "Complex software project development: agile methods adoption”, Journal of Software Maintenance and Evolution: Research and Practice, 23(8), (2011), pp. 549-564.

[37] Motwani J, Subramanian R, \& Gopalakrishna P., "Critical factors for successful ERP implementation: Exploratory findings from four case studies”, Computers in Industry, 56(6), (2005), pp. 529-544.

[38] Leyh C \& Sander P., "Critical Success Factors for ERP System Implementation Projects: An Update of Literature Reviews", In Enterprise Systems. Strategic, Organizational, and Technological Dimensions, Springer International Publishing, (2015), pp. 45-67.

[39] Sangari MS, Razmi J, \& Zolfaghari S., "Developing a practical evaluation framework for identifying critical factors to achieve supply chain agility", Measurement, 62, (2015), pp. 205-214.

[40] Fayezi S, Zutshi A, \& O'Loughlin A., "Developing an analytical framework to assess the uncertainty and flexibility mismatches across the supply chain", Business Process Management Journal, 20(3), (2014), pp. 362-391.

[41] Romero D, \& Vernadat F., "Enterprise information systems state of the art: past, present and future trends", Computers in Industry, (2016), pp. 79-13.

[42] Françoise O, Bourgault M, \& Pellerin R., "ERP implementation through critical success factors' management”, Business Process Management Journal, 15(3), (2009), pp. 371-394.

[43] Ali M. \& Miller L., "ERP System Implementation in Large Enterprises-A Systematic Literature Review", Journal of Enterprise Information Management, 30(4), (2017).

[44] Loforte Ribeiro F \& Timóteo Fernandes M., "Exploring agile methods in construction small and medium enterprises: a case study", Journal of Enterprise Information Management, 23(2), (2010), pp. 161-180.

[45] Shahane D, Jamsandekar P, \& Shahane D., "Factors influencing the agile methods in practice-Literature survey \& review", In Computing for Sustainable Global Development (INDIACom), International Conference on IEEE, (2014), pp. 556-560.

[46] Worley JH, Chatha KA, Weston RH, Aguirre O, \& Grabot B., "Implementation and optimisation of ERP systems: A better integration of processes, roles, knowledge and user competencies", Computers in Industry, 56(6), (2005), pp. 620-638.

[47] Ranjan S, Jha VK, \& Pal P., "Literature review on ERP implementation challenges", International Journal of Business Information Systems, 21(3), (2016), pp. 388-402.

[48] Lech P., "Managing knowledge in IT projects: a framework for enterprise system implementation", Journal of Knowledge Management, 18(3), (2014), pp. 551-573.

[49] Carvalho HL, \& Guerrini FM., "Reference model for implementing ERP systems: an analytical innovation networks perspective", Production Planning, (2017), pp. 1-14.

[50] Hummel M., "State-of-the-art: A systematic literature review on agile information systems development”, In 47th Hawaii International Conference on System Sciences, IEEE, (2014), pp. 47124721.

[51] Schniederjans D \& Yadav S., "Successful ERP implementation: an integrative model", BPM Journal, 19(2), (2013), pp. 364-398.

[52] Peci M \& Važan P., "The biggest critical failure factors in ERP implementation", In Applied Mechanics and Materials, Vol. 519, (2014), pp. 1478-1482.

[53] Laurie D Hughes, Nripendra P. Rana, Antonis C. Simintiras, "The changing landscape of IS project failure: an examination of the key factors", Journal of Enterprise Information Management, Vol. 30, (2017).

[54] Hassab Elnaby HR, Hwang W, \& Vonderembse MA, "The impact of ERP implementation on organizational capabilities and firm performance”, Benchmarking: An International Journal, (2012), pp. 618-633.

[55] Kitchenham, B., "Procedures for Performing Systematic Reviews", Joint Technical Report. Keele University \& National ICT Australia, (2014)

[56] Campanelli \& Parreiras, "Agile methods tailoring-A systematic literature review”, Journal of Systems and Software, 110, (2015), pp. 85-100.

[57] Kaushik, S., Bharadwaj, A., Awasthi, V., \& Sharma, R., "A Novel Framework for Requirement Prioritization for ERP Implementation”, Indian Journal of Science and Technology, 9(48), (2017).

[58] Wijaya S.F, Prabowo, H., Kosala, R. R. Meyliana, "Agile Methods for ERP Implementation: A Systematic Literature Review", In 2018 International Conference on Information Management and Technology (ICIMTech), IEEE, (2018), pp. 1-9. 